\title{
The Influence of Organizational Culture and Market Orientation on Performance of Microfinance Institutions in Kenya
}

\author{
Owino O. Joseph ${ }^{1} \&$ Kibera Francis ${ }^{1}$ \\ ${ }^{1}$ Department of Business Administration, University of Nairobi, Kenya \\ Correspondence: Owino Joseph Odhiambo, Department of Business Administration, University of Nairobi, P.O. \\ Box 30197, 00100 Nairobi, Kenya. Tel: 254-272-362-5988. E-mail: jowino@uonbi.ac.ke
}

Received: May 20, 2015

doi:10.5539/ijbm.v10n8p204

\author{
Accepted: June 9, 2015 Online Published: July 22, 2015 \\ URL: http://dx.doi.org/10.5539/ijbm.v10n8p204
}

\begin{abstract}
The objective of our study is to assess the influence of organizational culture and market orientation on performance. The population of the study comprise microfinance institutions that are members of the Association of Microfinance Institutions (AMFI) in Kenya. We used descriptive cross-sectional survey design. We collected primary data using structured questionnaire. We test our hypotheses through regression analysis. Our results demonstrate that organizational culture significantly and positively influence variations in performance. The partial mediation effect of market orientation on the relationship between organizational culture and performance was confirmed. The complimentary effect of organizational culture on market orientation implies that organizations need to spend more resources in nurturing market orientation to create sustainable competitive advantage through delivery of superior customer experience. We conclude that the influence of organizational culture and market orientation on performance is more plausible for mature industries regarded as diverse in terms of customer needs.
\end{abstract}

Keywords: organizational culture, market orientation, performance, microfinance

\section{Introduction}

Over the past few decades, researchers have focused on assessing the influence of organizational culture on performance. Although several articles link organizational culture with improved performance of the firm, little attention has been given to investigating the indirect influence of organizational culture on performance. While several behavioural variables including market orientation may either hinder or reinforce the influence of organizational culture on performance outcome, empirical evidence on the mediating influence of market orientation on organizational culture-performance relationship is scant. Organizational culture is defined as the general constellation of beliefs, mores, customs, value systems, behavioural norms and ways of doing business that are unique to each corporation (Tunstall, 1983). Although organizational culture is central to marketing management, its impact on marketing has not received satisfactory research attention (Deshpande \& Webster, 1989). In spite of studies that have tested the relationship between organizational culture and performance, inconsistent findings have been found (Deal \& Kennedy, 1982; Peters \& Waterman, 1982; Ott, 1989; Denison \& Mishra, 1995). Previous studies have focused more on direct relationship between organizational culture and performance (Kotter \& Heskett, 1992; Daft, 2007).

Market orientation is visualized through five standpoints consisting of the decision making perspective (Shapiro, 1988); the market intelligence perspective (Kohli \& Jaworski, 1990); and the culturally based behavioural perspective (Narver \& Slater, 1990). Other perspectives include the strategic marketing focus perspective (Ruekert, 1992); and the customer orientation perspective (Deshpande et al., 1993). The market intelligence perspective proposed by Kohli and Jaworski (1990) is an extension of the decision making perspective by Shapiro (1988). Marketing theorists have critiqued the narrow delineation of market intelligence perspective (Harris, 1996). As a result, the broad based cultural perspective has gained more support. The culturally based behavioural realm (Narver \& Slater, 1990; Deshpande et al., 1993) accentuates customer orientation, competitor orientation and inter-functional coordination as the main elements of market orientation.

Whereas several studies have tested the relationship between market orientation and performance, empirical evidence reveal variations in magnitude and direction of the relationship between these variables. Some researchers conclude that market orientation has insignificant impact on performance (Agarwal, Erramili \& Dev, 
2003; Sandvik \& Sandvik, 2003). Conversely, a positive relationship has been established by Slater and Narver (1994a), Grewal and Tansuhaj (2001), and Njeru (2013). While a positive link between market orientation and firm performance has been found, questions about the robustness of this relationship still lingers (Shoham, Rose \& Kropp, 2005). Therefore, it is apparent that empirical evidence on the relationship between market orientation and performance is inconclusive. As a result, our study attempts to unearth the influence of market orientation on the relationship between organizational culture and performance in the microfinance industry.

\section{Theoretical Perspective and Hypotheses}

Whereas theoretical assertions depict organizational performance as dependent on complex interactions in the environment, the resource based view theory of the firm and the dynamic capability theory predict organizational culture as key determinant of performance. The resource based view of the firm assumes sustainable competitive advantage as the desired outcome of management effort (Fahy \& Smithee, 1999). According to this theory, sustainable competitive advantage is obtained through accumulation and utilization of valuable resources that are difficult to duplicate by competitors. Collis and Montgomery (1995) suggest that sustainable competitive advantage can be created on condition that resources have the attributes of inimitability, durability, appropriability, substitutability, and competitive superiority. In essence, the theory suggests that unique, high value and rare organizational resources lead to superior performance through enhanced competitive advantage.

Resource-based theory suggests that firms possess heterogeneous resources that allow managers to execute value creating strategies. Even though it provides managers with a decision making framework, the theory has been criticized for failing to consider the impact of dynamic marketing environment (Lengnick-Hall \& Wolf, 1999) in which many firms operate. Besides, the theory fails to explain how resources are developed and deployed to achieve competitive advantage (Priem \& Butler, 2001). The dynamic capabilities theory addresses the weaknesses of the resource based theory. It argues that performance is explained by organizational capabilities for acquiring, accumulating and deploying resources in ways that reflect changing market conditions (Makadok, 2001; Teece et al., 1997). Capabilities are complex, structured and multi-dimensional. Marketing capabilities are developed through continuous application of marketing knowledge and skills possessed by employees to solving marketing problems (Vorhies, Harker, \& Rao, 1999; Zollo \& Winter, 2002).

\subsection{Organizational Culture and Performance}

Organizational culture plays an important role in shaping values and behaviour of organizational members. According to Deal and Kennedy (1982) performance improvement in an organization is associated with deliberate efforts by management towards developing organizational culture. In a related piece, Bennett et al. (1994) argue that organizational success depends on achieving a good fit between strategy, structure and culture. Giberson et al. (2009) consider culture as an integrating mechanism that guides organizational behaviour. Once established, culture tends to become self reinforcing.

Despite theoretical concord on the role of organizational culture in driving the behaviour of employees, several studies report inconsistent findings on the relationship between organizational culture and performance. A positive link has been empirically established by Deal and Kennedy (1982), Peters and Waterman (1982), and Denison and Mishra (1995). Conversely, Ott (1989) argues that culture is not universally relevant to all organizations and therefore, not all organizations possess a culture developed to a point that it could have significant influence on performance. In support of this view, Byles and Keating (1989) observe that the underdeveloped organizational culture may have little or no effect on performance. According to Byles, Aupperle and Arogyaswamy (1991) organizational culture is only a relevant predictor of performance where it is consistent with critical success factors. Clearly, the debate on the influence of organizational culture on performance is far from over. Consistent with Denison and Mishra (1995) we predict that:

Hypothesis 1: Organizational culture significantly and positively influences performance of microfinance institutions

\subsection{Organizational Culture, Market Orientation and Performance}

At first sight, there might appear to be overlap between organizational culture and market orientation constructs (Pinho, Rodrigues \& Dibb, 2013). However, in this study, we treat market orientation as a set of behaviours that exist in varying degrees among firms in the industry. Market orientation implies an expanded focus that pays balanced attention to both customers and competitors (Kohli \& Jaworski, 1990). Marketing studies suggest that market orientation is a set of specific behaviours and activities; a resource; a basis for decision making; and an aspect of organizational culture. McCarthy and Perreasult (1990) argue that market orientation differs from marketing orientation in the sense that marketing orientation is concerned with implementation of the marketing 
concept. In the same vein, Lafferty and Hult (2001) clarify that market orientation focus on instituting the marketing concept.

According to Narver and Slater (1990) market orientation consists of three behavioural components namely: customer orientation, competitor orientation and inter-functional coordination. They argue that on average, all the three components are equally important. Customer orientation and competitor orientation are concerned with organization's long-term decisions to improve business performance (Gatignon \& Xuereb, 1997). Similarly, Kohli and Jaworski (1990) explain that customer orientation facilitate gathering of relevant, accurate and timely information from target market that enables a firm to sustain superior competitive advantage. The direct relationship between market orientation and performance has been studied over a long period of time. Previous studies provide equivocal results on the relationship between market orientation and performance. A positive relationship between market orientation and organizational performance has been established (Grinstein, 2008; Zebal \& Goodwin, 2012). More recently, Njeru (2013) established a positive relationship between market orientation and performance of tour operators in Kenya. Other researchers have reported insignificant link between market orientation and performance (Agarwal, Erramili, \& Dev, 2003; Sandvik \& Sandvik, 2003).

The existence of such equivocal results reinforces the need for more studies on the relationship between market orientation and performance. Previous studies indicate the existence of a positive relationship between organizational culture and market orientation (Grinstein, 2008; Mcchlure, 2010). Even though researchers argue that organizational culture supports implementation of market orientation, there is little empirical evidence to support this claim. While several researchers have devoted more attention to explaining the nature of culture, fewer articles have been contributed on the relationships among organizational culture, market orientation and performance in an integrated manner.

Several studies have tested the direct influence of market orientation on performance (Sandvik \& Sandvik, 2003; Cano et al., 2004; Kirca et al., 2005; Shoham et al., 2005; Grinstein, 2008; Zebal \& Goodwin, 2012; Njeru, 2013). However, the mediating influence of market orientation has not been empirically tested. Instead, previous studies on organizational culture and market orientation relationship tend to configure organizational culture as a mediating variable (Baron \& Kenny, 1986). As a result, the mediating influence of market orientation is unclear. Therefore, we explicate the mediating role of market orientation by testing the following hypotheses:

Hypothesis 2: The relationship between organizational culture and performance of microfinance institutions is significantly mediated by market orientation

Hypothesis 3: The joint effect of organizational culture and market orientation on performance is statistically significant

\section{Methodology}

Our study tests hypotheses developed from existing theory. Therefore, we adopt positivist theory and descriptive cross-sectional survey research design. The selection of this design is guided by research objectives, the nature of relationships tested; type of data and the span of data collection. The target population comprises all microfinance institutions in Kenya that are members of the Association of Microfinance Institutions in Kenya (AMFI). The population is constituted as follows: 5 commercial banks offering microfinance services; 5 wholesale microfinance lenders; 16 deposit taking micro-finance institutions (DTM); and 29 retail microfinance lenders.

Organizational culture was measured through 12 items based on organizational culture assessment indicator (OCAI) scale. Market orientation was measured using the MARKOR scale (Kohli, Jaworski \& Kumar, 1993). Performance was measured using 12 perceptual indicators of firm performance. Respondents were asked to indicate on a five point rating scale, the extent to which each of the items of organizational culture and market orientation matched their organization. In addition, respondents were asked to rate the performance of their organization on a scale of 1 to 5 where 1 symbolized 'much worse than competitors' and 5 anchored 'much better than competitors'.

Although our measurement scales were adopted from literature, they were modified to fit the objectives of the current study. Consequently, a pilot study was conducted to assess the reliability of measurement scales. We pre-tested the questionnaire by administering it to senior managers of deposit taking co-operative societies in Nairobi City. Reliability was tested through internal consistency technique by computing Cronbach's alpha. Consistent with Cooper and Schindler (2006) we interpret alpha coefficient of 0.7 and above to mean satisfactory reliability. Cronbach's alpha coefficient ranged from 0.819 (organizational culture) to 0.903 (market orientation) revealing a high degree of reliability. Performance had a reliability score of 0.896 . We revised the questionnaire 
after the pilot test. We collected data using structured questionnaire targeting marketing manager, human resource manager and Chief Executive Officer from each institution. Aggregated individual scores were used to reduce one source response bias.

Content validity was enhanced by adopting established measurement scales from literature. We used the average variance extracted (AVE) technique to test convergent validity. Our analysis shows that organizational culture and performance had AVE of 0.66 and 0.77 respectively. Marketing orientation had AVE of 0.77. The tests show that all our variables had satisfactory convergent validity. Construct validity was tested through factor analysis. To avoid Type I and Type II errors, we subjected our data to tests for the assumptions of the regression analysis. Specifically, we tested for linearity, reliability of measurement, homoscedasticity and normality. Normality was tested through P-P plots. The relationships between independent and dependent variables were examined for linearity. Homoskedasticity was checked by visual examination of the standardized residuals.

We test our hypotheses through regression analysis. Specifically, we regressed organizational culture on hypothesized performance. The mediating influence of market orientation on the relationship between organizational culture and firm performance was tested through the four steps of path analysis proposed by Baron and Kenny (1986). We used the technique to analyze the direct and indirect influence of organizational culture on performance. We predicted that organizational culture indirectly influences performance through market orientation.

\section{Results}

Out of the 54 MFIs contacted, one declined to participate while 53 organizations successfully completed questionnaires translating to a response rate of $96 \%$. Our results indicate that organizational culture has a significant positive influence on performance with a coefficient of determination $\left(\mathrm{R}^{2}\right)$ of 0.409 , a standardized beta coefficient of 0.640 and $\mathrm{F}$ statistics of 35.31. The results demonstrate overall significance of the model and show that organizational culture explains $40.9 \%$ of the variation in firm performance. Therefore, our first hypothesis is supported.

Table 1. Regression results for the relationship between organizational culture and non financial firm performance

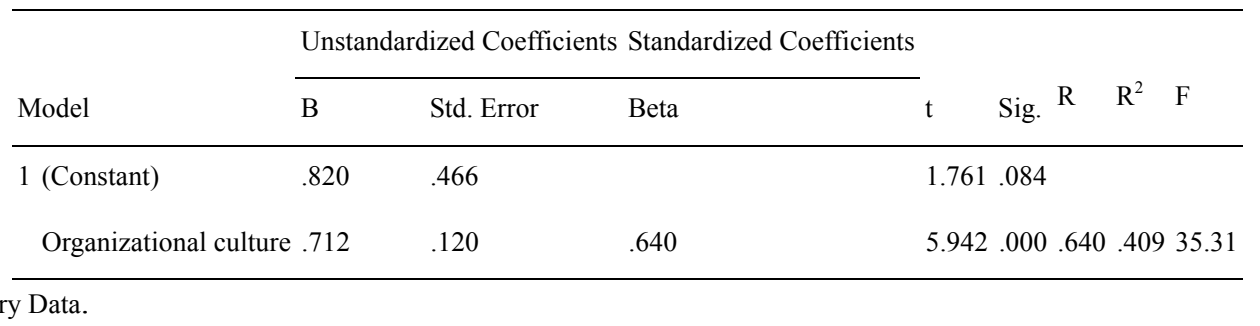

Source: Primary Data.

Mediation was tested through three regression models. Results displayed in Table 2 shows that all the models were significant. However, the standardized beta coefficient (std. beta $=0.345$ ) for organizational culture in model 2 was less than standardized beta coefficient $($ std. beta $=0.640)$ for the predictor variable in model 1 . In the second model, both organizational culture and market orientation were significant. The significance of organizational culture in model 2 shows that it has indirect effect on firm performance through market orientation. Therefore, the results confirm partial mediation of market orientation on the relationship between organizational culture and performance. 
Table 2. Mediating influence of market orientation on the relationship between organizational culture and performance

\begin{tabular}{|c|c|c|c|c|c|c|c|c|c|c|}
\hline \multirow[b]{3}{*}{ Model } & & \multirow{2}{*}{\multicolumn{2}{|c|}{$\begin{array}{l}\text { Unstandardized } \\
\text { Coefficients }\end{array}$}} & \multirow{3}{*}{$\begin{array}{l}\text { Standardized } \\
\text { Coefficients } \\
\text { Beta }\end{array}$} & \multirow[b]{3}{*}{$\mathrm{t}$} & \multirow[b]{3}{*}{ Sig. } & \multicolumn{2}{|c|}{$95.0 \%$ Confidence } & \multirow{2}{*}{\multicolumn{2}{|c|}{ Collinearity Statistics }} \\
\hline & & & & & & & \multicolumn{2}{|c|}{ Interval for B } & & \\
\hline & & $\mathrm{B}$ & Std. Error & & & & $\begin{array}{l}\text { Lower } \\
\text { Bound }\end{array}$ & $\begin{array}{l}\text { Upper } \\
\text { Bound }\end{array}$ & Tolerance & VIF \\
\hline \multirow[t]{2}{*}{1} & (Constant) & .820 & .466 & & 1.761 & .084 & -.115 & 1.755 & & \\
\hline & Organizational culture & .712 & .120 & .640 & 5.942 & .000 & .472 & .953 & 1.000 & 1.000 \\
\hline \multirow[t]{3}{*}{2} & (Constant) & .687 & .450 & & 1.526 & .133 & -.217 & 1.591 & & \\
\hline & Organizational culture & .384 & .181 & .345 & 2.116 & .039 & .020 & .748 & .402 & 2.489 \\
\hline & Market orientation & .403 & .172 & .381 & 2.343 & .023 & .057 & .749 & .402 & 2.489 \\
\hline
\end{tabular}

Note. a. Dependent Variable: Organizational non financial performance

Results for test of the joint influence of organizational culture and market orientation on performance were statistically significant. Therefore, our third hypothesis is supported. Inspection of Table 3 shows that the combined influence of organizational culture and market orientation on performance was greater than the unilateral influence of either organizational culture or market orientation on performance. Organizational culture and market orientation jointly explain $46.8 \%$ of the variations in performance $\left(\mathrm{R}^{2}=.468\right)$.

Table 3. Regression summary results for organizational culture, market orientation and performance

\begin{tabular}{llllllllll}
\hline \multicolumn{1}{c}{} & \multicolumn{9}{c}{ Change Statistics } \\
Model & $\mathrm{R}$ & $\mathrm{R}^{2}$ & $\begin{array}{l}\text { Adjusted } \\
\text { Square }\end{array}$ & $\begin{array}{l}\text { R Std. Error } \\
\text { the Estimate }\end{array}$ & Change & F Change & df1 & df2 & Sig. F Change \\
\hline 1 & $.640^{\mathrm{a}}$ & .409 & .398 & .46784 & .409 & 35.311 & 1 & 51 & .000 \\
2 & $.684^{\mathrm{b}}$ & .468 & .446 & .44852 & .058 & 5.488 & 1 & 50 & .023 \\
\hline
\end{tabular}

a. Predictors: (Constant), Organizational culture.

b. Predictors: (Constant), Organizational culture, Market orientation.

\section{Discussion}

A major contribution of our study is the evaluation of the direct and indirect influence of organizational culture on performance. The model testing the influence of organizational culture on performance fits well in terms of explanatory power and renders support to the resource based theory and the dynamic capabilities theory. Our results suggest that besides the indirect path postulated by the dynamic capability theory, organizational culture is directly linked to performance. Consistent with Deal and Kennedy (1982); Peters and Waterman (1982); Denison (1984); and Denison and Mishra (1995) our results support existence of positive association between organizational culture and performance. However, the findings are incompatible to results obtained by Ott (1989); and Byles and Keating (1989). Our results play a crucial role in demonstrating the potential role of organizational culture in building and sustaining competitive advantage and subsequently improved performance.

Unlike other resources that can be easily acquired by competitors, organizational culture is an enduring differentiating asset that uniquely positions firms in the market and instigates provision of superior customer value. Our results demonstrate that possession of strong, deeply internalized and widely socialized culture has significant positive influence on performance. Although organizational culture is positively associated with performance, the possibility of a negative relationship cannot be ruled out. The nature of relationship between organizational culture and performance depends on the type and strength of the dominant culture within an organization. Therefore, organizational culture that is inconsistent with goals and strategies of the firm may negatively affect performance.

Several studies have concentrated on investigating the direct link between market orientation and performance (Narver \& Slater, 1990; Ruekert, 1992; Kohli, Jaworski, \& Kumar, 1993). In other words, little research attention 
has been directed towards establishing the mediating influence of market orientation on the relationship between organizational culture and performance. Beyond the mere link between organizational culture and performance, our findings demonstrate that market orientation partially mediates the relationship between organizational culture and performance. Although organizational culture and marketing orientation independently contribute towards firm performance, market orientation makes greater contribution than organizational culture when they are acting together. This suggests that organizational culture compliments market orientation to positively influence performance. Considering that organizational culture consists of a mix of sub-cultures, it therefore reinforces cultural values that are consistent with market oriented behaviours resulting to enhanced influence on performance.

\section{Conclusion}

Our study has demonstrated that presence of organizational culture and market orientation is critical to performance. The study offers interesting prospect to practitioners. Results of the study reveal that managers need to emphasize creation and adoption of market oriented culture to achieve and sustain superior performance. An important implication of this study is that emphasis by organizations on market intelligence generation; sharing; and responsiveness do not preclude the influence of overall organizational culture on performance. Rather, the overriding organizational culture complements market orientation leading to enhanced performance in the long term. Consequently, managers need to pay closer attention to facilitating adoption of market orientation by organizational members.

Organizational culture and market orientation are factors under the control of management. Creation of organizational culture is an exercise that takes time and effort. Therefore, we conclude that the contribution of organizational culture to performance is more relevant among established organizations than relatively young enterprises. Market orientation is more relevant for competitive industries characterized by heterogeneity of customer needs. Therefore, under conditions of homogenous customer needs and relatively stable markets, market orientation may have little influence on performance.

\section{Future Research}

The cross-sectional research design adopted in the study limits assessing the long-term influence of organizational culture and market orientation on performance. Considering that the gains from organizational culture and market orientation are not easily observable in the short term, there is need for using longitudinal research design in assessing the influence of organizational culture on performance. Despite the fact that positive and strong influence was established between organizational culture and performance, methodological variation is necessary in assessing the relationship. Although the dynamic capability theory explains how resources are developed and deployed, it does not shed light on organizational factors that influence reconfiguration of resources and how this process influences performance outcomes. Therefore, research driven towards theory development is of great concern.

\section{References}

Agarwal, S., Erramilli, M. K., \& Dev, D. C. (2003). Market orientation and performance in service firms: Role of innovation. Journal of Service Marketing, 17(1), 68-82. http://dx.doi.org/10.1108/08876040310461282

Baron, R. M., \& Kenny, D. A. (1986). The moderator-mediator variable distinction in social psychological research: Conceptual, strategic and statistical considerations. Journal of Personality and Social Psychology, $51,1173-1182$.

Bennett, R. H., Fadil, P. A., \& Greenwood, R. T. (1994). Cultural alignment in response to strategic organizational change: new considerations for a change framework. Journal of Managerial Issues, 6(4), 474-490.

Byles, C. M., \& Keating, J. R. (1989). Strength of organization culture and performance: Strategic implications. Journal of Business Strategies, 6, 42-54.

Byles, M. C., Aupperle, E. K., \& Arogyaswamy, B. (1991). Organizational culture and performance. Journal of Managerial Issues, 3(4), 512-527.

Cano, C., Carrillat, F., \& Jaramillo, F. (2004). A meta-analysis the relationship between market orientation and business performance. International Journal of Research in Marketing, 21, 179-200.

Collis, D. J., \& Montgomery, C. A. (1995). Competing on resources: Strategy in the 1990s. Harvard Business School, $118-128$.

Cooper, R. D., \& Schindler, S. P. (2006). Business Research Methods (9th ed.). McGraw Hill. 
Daft, R. L. (2007). Organizational Theory and Design (9th ed.). South-Western, Cincinnati, OH.

Deal, T. E., \& Kennedy, A. A. (1982). Corporate Cultures: The Rites and Rituals of Corporate Life. Reading, Massachusetts: Addison-Wesley.

Denison, D. R. (1984). Bringing corporate culture to the bottom line. Organizational Dynamics, 5(22).

Denison, D. R., \& Mishra, A. K. (1995). Towards a theory of organizational culture and effectiveness. Organization Science, 6, 204-223. http://dx.doi.org/1047-7039/95/0602/0204

Deshpande, R. (1993). Culture, customer orientation, and innovativeness in Japanese Firms: A quadrad analysis, Journal of Marketing, 57(January), 23-27. http://dx.doi.org/10.2307/1252055

Deshpande, R., \& Webster, E. F. (1989). Organizational Culture and Marketing: Defining the Research Agenda. Journal of Marketing, 53, 3-15.

Fahy, J., \& Smithee, A. (1999). Strategic marketing and the resource based view of the firm. Academy of Marketing Science Review, 10, 1-18

Gatignon, H., \& Xuereb, J. M. (1997). Strategic orientation of the firm and new product performance. Journal of Marketing Research, 34(February), 77-90. http://dx.doi.org/10.2307/3152066

Giberson, R. T., Resick, J. C., Dickson, W. M., Mitchelson, K. J., Randall, R. K., \& Clark, A. M. (2009). Leadership and organizational culture: linking CEO characteristics to cultural values. Journal of Business Psychology, 24, 123-137. http://dx.doi.org/10.1007/s10869-009-9109-1

Grewal, R., \& Tansuhaj, P. (2001). Building organizational capabilities for managing economic crisis: The role of market orientation and strategic flexibility. Journal of Marketing, 65(April), 67-80.

Grinstein, A. (2008). The effect of market orientation and its components on innovation consequences: A meta-analysis. Journal of the Academy of Marketing Science, 36(2), 166-173. http://dx.doi.org/10.1007/s11747-007-0053-1

Grinstein, A., \& Xuereb. (2008). The relationship between market orientation and alternative strategic orientations-a meta analysis. European Journal of Marketing, 42(1), 115-134. http://dx.doi.org/10.1108/03090560810840934

Kirca, H. A., Jayachandran, S., \& Bearden, O. W. (2005). Market orientation: A meta-analytic review and assessment of its antecedents and impact on performance. Journal of Marketing, 69, 24-41.

Kohli, A. K., \& Jaworski, J. B. (1990). Market orientation: The construct, research propositions, and managerial implications. Journal of Marketing, 54(April), 1-18.

Kohli, A. K., Jaworski, J. B., \& Kumar, A. (1993). MARKOR: A measure of market orientation. Journal of Marketing Research, 30, 467-477.

Kotter, J. P., \& Heskett, J. L. (1992). Corporate Culture and Performance. New York: Free Press.

Lafferty, A. B., \& Hult, M. T. (2001). A Synthesis of contemporary market orientation perspectives. European Journal of Marketing, 35(1), 92-109. http://dx.doi.org/10.1108/03090560110363364

Lengnick-Hall, C. A., \& Wolf, J. A. (1999). Similarities and contradictions in the core logic of three strategy research streams. Strategic Management Journal, 20(12), 1109-1132.

Makadok, R. (2001). Toward a synthesis of the resource-based and dynamic capability views of rent creation. Strategic Management Journal, 22(5), 387-401. http://dx.doi.org/10.1002/smj.158

McCarthy, J. E., \& Perreault, W. D. Jr. (1990). Basic Marketing-A Managerial Approach (10th ed.). Irwin, Homewood, IL.

Mcclure, R. E. (2010). The influence of organizational culture and conflict on market orientation. Journal of Business Industrial Marketing, 25(7), 514-524. http://dx.doi.org/10.1108/08858621011077745

Narver, J. C., \& Slater, E. S. (1990). The effect of a marketing orientation on business profitability. Journal of Marketing, 54(October), 20-35.

Njeru, G. W. (2013). Market orientation, marketing practices, firm characteristics, external environment and performance of tour firms in Kenya. Unpublished Doctoral Thesis. School of Business, University of Nairobi.

Ott, J. S. (1989). The organizational culture perspective. Pacific Grove, Calif: Brooks/Cole. 
Peters, T. J., \& Waterman, H. R. (1982). In Search of Excellence: Lessons from America's Best-run Companies. New York: Harper and Row.

Pinho, C. J., Rodrigues, P. A., \& Dibb, S. (2013). The role of corporate culture, market orientation and organizational commitment in organizational performance: The case of non-profit organizations. Journal of Management Development, 33(4), 374-398. http://dx.doi.org/10.1108/JMD-03-2013-0036

Priem, R. L., \& Butler, J. E. (2001). Is the resource-based view a useful perspective for strategic management research? Academy of Management Review, 26(1), 22-40.

Ruekert, R. W. (1992). Developing a market orientation: an organizational strategy perspective, International Journal of Research in Marketing, 9, 225-245.

Sandvik, I. L., \& Sandvik, K. (2003). The impact of market orientation on product innovativeness and business performance. International Journal of Research in Marketing, 20(4), 355-76

Shoham, A., Rose, M. G., \& Kropp, F. (2005). Market orientation and performance: A meta-analysis. Marketing Intelligence \& Planning, 23(5), 435-454. http://dx.doi.org/10.1108/02634500510612627

Slater, S. F., \& Narver, C. J. (1994). Does competitive environment moderate the market-orientation-performance relationship. Journal of Marketing, 58, 46-55.

Teece, D. J., Pisano, G., \& Shuen, A. (1997). Dynamic capabilities and strategic management. Strategic Management Journal, 18(7), 509-535. http://dx.doi.org/10.1002/(SICI)1097-0266(199708)18:7

Tunstall, W. B. (1983). Cultural transformation at AT \& T. Sloan Management Review, 25(1), 15-26.

Vorhies, W. D., Harker, M., \& Rao, P. C. (1999). The capabilities and performance advantages of market-driven firms. European Journal of Marketing, 33(11), 1171-1202. http://dx.doi.org/10.1108/03090569910292339

Zebal, A. M., \& Goodwin, R. D. (2012). Market orientation and performance in private universities. Marketing Intelligence \& Planning, 30(3), 339-357. http://dx.doi.org/10.1108/02634501211226302

Zollo, M., \& Winter, S. G. (2002). Deliberate learning and the evolution of dynamic capabilities. Organizational Sciences, 13, 339-351.

\section{Copyrights}

Copyright for this article is retained by the author(s), with first publication rights granted to the journal.

This is an open-access article distributed under the terms and conditions of the Creative Commons Attribution license (http://creativecommons.org/licenses/by/3.0/). 